\title{
HOW GOVERNANCE COUNTS? COMPARATIVE ANALYSIS OF ACTIVITY AND FUNDING PATTERNS OF CENTRAL EUROPEAN CROSS-BORDER COOPERATION PROGRAMMES
}

\author{
Zoltán Pámer (D) \\ Centre for Economic and Regional Studies, Hungarian Academy of Sciences \\ Tóth Kálmán u. 4., H-1097, Budapest: Hungary \\ pamer@rkk.hu
}

\begin{abstract}
Cross-border cooperation - as objective 3 of cohesion policy since the 2007-2013 programming period - plays a key role in promoting Europeanisation, which is especially important in case of Central Europe that is dominated by small national states. Target areas of cross-border cooperation are the NUTS 3 units located along the state borders. As project generation, decision making and implementation is overwhelmingly done on regional level, territorial governance structures are decisive from cross-border cooperation point of view. The paper focuses on two programmes - the Slovenia-Austria and the Hungary-Croatia - whose target areas are lacking large urban centres, middle-size and small towns make up the backbone of the settlement network. The involved countries are very diverse in regional governance structures. Austria is a federal state with strong regional governments. Croatia and Hungary are unitary states with limited capacities on regional level. Slovenia is, again, a unitary state that lacks medium level of government, therefore the local level is the carrier of cross-border cooperation. Aim of the paper is to identify how different systems of territorial governance are reflected in the implementation of the programme and the allocation of funding. After presenting the premises of cross-border cooperation and a brief outline of the two programmes a quantified analysis will be presented based on primary ex-post programme data of the 2007-2013 Slovenia-Austria and Hungary-Croatia cross-border cooperation programmes. Analysis is conducted on LAU 2 level in order to show how different categories of the settlement structure contribute in terms of cooperation activity and absorption and how it is distributed between different types of beneficiary organisations.
\end{abstract}

Keywords: cohesion policy, territorial governance, cross-border cooperation, Central European countries.

\section{Significance of cross-border cooperation}

Border areas are usually considered as peripheral regions being isolated from the hinterlands and lagging behind in terms of economic and social development. Europe with its fragmented structure of national states means most of Europe's regions are border regions. The European integration process, from its very beginning, triggered the border issue: integration of the European national economies in line with comparative advantages. The role of border regions has even been strengthened after accession of new member states to the European Union (EU) in 2004 when coun- 
tries of below-average size and land-locked position have become members. This growing interest towards border regions is also reflected in the geographical literature, the shift in approach towards cross-border issues. In the early 1990s, instead of focusing on cross-border flows of economic activities and their discontinuity, the "cross-border cooperation approach" (van Houtum 2000: 63) rather focused on different forms of cooperation within the single market in a policy-oriented way, that provides border regions opportunities and access to networks (van Houtum 2000).

European cohesion policy - dating back to the setup of the European Regional Development Fund in 1975 - put a clear stress on catching up of the regions lagging behind. In 1984 the tool of Community Initiatives was introduced, opening up to interventions of community significance (Manzella \& Mendez 2009). One of them, the INTERREG Community Initiative introduced 1998, targeted border regions (Harguindéguy \& Bray 2009). In the first programming period (1990-1993) dominantly border areas of the objective 1 cohesion regions were preferred (AEBR 1997). The Maastricht Treaty was an important milestone in establishment of the legal background of cross-border cooperation, through the promotion of the subsidiarity principle, enabling that development programmes - including cross-border ones - shall be designed in line with locally defined objectives. The INTERREG II initiative (1994-1999) set up the pillar system of INTERREG, separating cross-border cooperation from wider, transnational cooperation schemes. Parallel, for regions along external borders of the EU tailor-made schemes such as PHARE CBC and TACIS were launched (Perkmann 2003). The pillar system has been more fine-tuned in the 2000-2006 programming period, where cross-border cooperation (pillar A), transnational cooperation (pillar B) and interregional cooperation (pillar C) were distinguished (INTERACT 2015). In this period role of the subnational level has been strengthened (Harguindéguy \& Bray 2009): representatives of border regions have been more operationally involved in programming, project selection and monitoring, however in case of transnational and interregional programmes the national states dominated. In this programming period already the 2004 accessing new member states could participate, albeit in a limited timeframe and somewhat limited financing. In order to ensure transition from rigid pre-accession assistance to more flexible INTERREG funding, so called Neighbourhood Programmes have been set up, with participation of member states and candidate countries (VÁTI 2004). Since 2007 European Territorial Cooperation (ETC) has been declared as 'objective 3' of cohesion policy, cross-border cooperation - instead of Community Initiative - has become part of the EU structural policy's mainstream (Pámer 2011). Further novelty of the period was that cooperation along external borders has become part of the general regulation, emphasising that its role in coping with regional imbalances (EC 2006: Preamble 21). Such harmonisation of pre-accession assistance with ERDF funding makes comparison of different programmes feasible.

Cross-border cooperation has been an important tool in the Europeanisation of the peripheries (Scott \& Liikanen 2010), already prior to the 2004 accession. Euroregions established on peripheries of the EU (Perkmann 2007) were a tool practicing multi-level governance, exchange of practices and reducing regional disparities (Popescu 2008). For the sake of involving regions located on peripheries (Bojar 2008) or outside the EU, tailor-made tools have been developed including the CARDS programme for the countries of the former Yugoslavia. PHARE and CARDS were in the 2007-2013 programming period replaced by IPA (Instrument for Pre-Accession) that had a particular component for cross-border cooperation (Dubarle et al. 2011), aiming at both intensifying cooperation between the states of the Western Balkans and these states with the EU member states.

As Scott (2013) highlights, cross-border cooperation, in general, is considered as a special tool of transmitting European values, part of the progressive identity of the EU, however it might be criticised as cooperation is interest-driven and substitutes other funding sources (Scott 2013). 
In the target area of the paper several scholars highlighted added values of part cross-border cooperation programmes, including Lados (2005) for Austria-Hungary, Csapó et el. (2015) for Hungary-Croatia or Zimmermann and Kubik (2003) for Slovenia-Austria.

\section{System of territorial governance in the investigated countries}

The four investigated countries - Austria, Croatia, Hungary and Slovenia - have significantly different systems of territorial governance, which dates back to historical circumstances and the self-definition of two newly independent post-Yugoslav countries.

Austria, being a federal state, has strong regional governments on NUTS 2 level, which is responsible for spatial planning and regional development. Even if the national state does some sort of coordination through the Austrian Spatial Planning Conference (Österreichische Raumordnungskonferenz - ÖROK), the single states follow slightly different approach in their spatial policies (ÖREK 2010). NUTS 3 level in Austria is the "group of districts", which does not have an elected body, but are composed of one or more units of state administration. Regional development, as manifestation of territorial governance, takes place on regional level, below the NUTS 2 regions, through locally and regionally funded Regionalmanagement bodies, responsible for management of EU funding, project generation and information (Bundeskanzleramt, ÖSB Consulting 2004).

Slovenia has no politically elected regional level, however there were attempts to create them (Delo 2008). According to the law of regional development on NUTS 3 level (statistical regions) the community of local governments sets up regional development councils (Zakon 2011). Besides the council, local governments may set up regional development agencies as well (Zakon 2011), however their territorial coverage varies: some operate on NUTS 3 level, some below, with significant differences in capacities (Lindstrom 2005). The development of Pomurje, on northeast of the country bordering with Austria, Croatia and Hungary - as the least developed region in Slovenia - is promoted by a special law and multi-annual state funding scheme for improvement of competitiveness and employment (Zakon 2009).

Although the territorial structure of counties in Hungary is considered as a thousand year old heritage, regionalisation of the country had been an issue on the table since adoption of the 1996 regional development act (Pálné Kovács 2009). Regionalisation, besides promotion of cooperation between the counties through setting up of regional development councils on NUTS 2 level resulted a growing influence of the state as well, as number of state-delegated members in the councils has been constantly risen (Rechnitzer 2012). The new regional development act seized the regional councils in 2011 and the counties (NUTS 3) have become responsible for regional development. The transformation was accompanied by a local government reform: counties have lost their competences and properties in public service provision (secondary education and health care) and "regional development, rural development, spatial planning and coordination" (Törvény 2011: 27. § (1)) has become their sole competence.

In Croatia the current county system has been introduced after independence (1992-1993), being a local body of the central government. Since the constitutional reform in 2000 it has become a politically elected regional government (Ivanišević et al. 2001). Due to the significant damages caused by the war, Croatia has introduced different tools and assistance schemes for various lagging behind areas (Pámer 2007; Đulabić \& Manojlović 2011). Currently applicable regional development law has been enacted in 2014 , defining the county as the coordinator of regional 
development on regional level, through its assembly and the public institution established by the county (Zakon 2014). On level of the two NUTS 2 regions delegated partnership councils have been set up, that are coordinated by the government (Zakon 2014) and have no structures.

As to compare the analysed countries, their territorial governance structures and practices are very different. NUTS 2 regions with own structures exist only in Austria - not counting the Hungarian experience with the development regions until 2011, in the other countries this level exists for statistical purposes only, with minimal coordination functions (Table 1). On the other hand NUTS 3 is operational in all analysed countries, however with different structures. While Hungary and Croatia has politically elected bodies, in Slovenia and Austria bottom-up local development bodies exist, owned by the local governments.

Table 1. Overview of decision making bodies in the investigated countries

\begin{tabular}{|l|l|c|l|l|}
\hline NUTS level & \multicolumn{1}{|c|}{ Slovenia } & \multicolumn{1}{c|}{ Austria } & \multicolumn{1}{c|}{ Hungary } & \multicolumn{1}{c|}{ Croatia } \\
\hline NUTS 2 & $\begin{array}{l}\text { Cohesion region } \\
\text { (delegated council) }\end{array}$ & $\begin{array}{l}\text { Province (elected } \\
\text { assembly) }\end{array}$ & $\begin{array}{l}\text { Until 2011: development } \\
\text { region (delegated council) }\end{array}$ & $\begin{array}{l}\text { Statistical region } \\
\text { (delegated partnership } \\
\text { council) }\end{array}$ \\
\hline NUTS 3 & $\begin{array}{l}\text { Development region } \\
\text { (delegated council) }\end{array}$ & - & County (elected assembly) & $\begin{array}{l}\text { County (elected } \\
\text { assembly) }\end{array}$ \\
\hline
\end{tabular}

Source: own edition.

\section{Institutionalisation of cross-border cooperation in the investigated area}

Cooperation of Austria and Slovenia is based on a historical heritage of the Habsburg Empire: current Slovenian territories had been integrated into the economic space of the monarchy; collaboration between these regions was an everyday practice until the Word War I.

As for the period of the Socialist Federal Republic of Yugoslavia (SFRY), cooperation dates back to the signature of the Trigon Cooperation Agreement in 1965, between Slovenia - as a republic within SFRY - Carinthia (Kärnten) and the Italian region of Friuli-Venezia-Giulia. This cooperation - which was later accessed by Croatia in 1969 (Quadrigon) - served as precursor for the Alps-Adriatic Working Community (AAWC) (Nadalutti 2015: 9). Even if AAWC played a key role in promotion of regional level cooperation, it has lost its position after the EU enlargement in 2004. As for socialist Slovenia, participation in these cooperation initiatives has opened space for positioning as a Western-oriented sub-state actor. 1991 independence and nation state building process has resulted a "newly centralised Slovenia" (Nadalutti 2015: 5), without any medium tier of governance, thus very reluctant about cooperation schemes on regional level.

Besides AAWC various further forms of Slovenia-Austria cooperation have emerged. The Euroregion Styria-Slovenia was founded in 2001, based on the historic Maribor-Graz cooperation (Zimmermann \& Kubik 2003), with institutionalisation ambitions (Land Steiermark 2016). The "EU Future Region" (Zukunfstregion) concept was based on various INTERREG projects (e.g. Conspace, Matriosca) (CADSES 2006), however institutionalisation efforts have not become successful, partially due to the strict Slovenian approach, as they stuck to the involvement of the national bodies (Nadalutti 2015).

As for Hungary and Croatia, in the 1950s when Yugoslavia and the Soviet Union opted for a different model of socialist system, the border between Hungary and the SFRY has become a strongly guarded dividing line, part of the Iron Curtain (Hajdú 1996). The 1970s brought a significant ease 
in the situation, resulting intensive cooperation in various economic sectors and intensive shopping tourism between the two sides (Bali 2012). War events in the early 1990s generated a pro-Croatian attitude in Hungarian officials, which was expressed by the early acknowledging of the sovereign Croatian state (Rácz 2016). This was followed by a period of intensive economic cooperation dominated by large corporations and several acquisitions from Hungarian side. In spite of these positive events interaction along the still heavily dividing border, as that are mostly the rivers of Drava and Mura, has remained minimal, infrastructure development suffered significant delays, being this border are the least permeable one of Hungary, with an average distance of border crossings being at $50 \mathrm{~km}$ (Rácz 2017). Institutionalisation attempts were manifested through the establishment of the Danube-Drava-Sava Euroregion in 1998, involving - besides Hungarian and Croatian counties - cantons from Bosnia and Herzegovina and observers from Vojvodina, Serbia and Montenegro (later Serbia) (CESCI 2016). Although the Euroregion is still existing, it is not operational anymore. In the recent years initiatives for setting up European Groupings for Territorial Cooperation (EGTC) have emerged, so far two such institutions operate in the Croatia-Hungary border area (Svensson \& Ocskay 2016).

\section{The investigated cross-border cooperation programmes}

The Slovenia-Austria Cross-border Cooperation Programme running in 2007-2013 provided an ERDF co-financing of 67 million euros (CBC 2007: 66), generating a total investment of 79 million euros. Programme coordination was carried out by joint management structures led by the Slovenian partner.

Target area of the programme was composed of nine NUTS 3 regions of Austria from three regions (Burgenland, Carinthia, Styria - Steiermark) and six statistical regions from Slovenia. Austrian part of the target area lags behind the Slovenian side in terms of population density, as both of the two large urban areas of Slovenia (Ljubljana, Maribor) were involved, while in Austria the urban areas of Graz and Klagenfurt were accompanied with dominantly rural areas. The programme had two priorities: competitiveness, knowledge and economic cooperation; and sustainable and balanced development. In terms of beneficiaries, project size and nature of projects there were no differences: beside non-profit organisations private small and medium sized enterprises were also eligible. Project size varied between 30 thousand and 3 million euros.

The 2007-2013 Hungary-Croatia IPA Cross-border Cooperation Programme consisted of 54.8 million euros of co-financing and a total investment of 68.8 million euros (CBC 2013: 94). Joint management structures were set up, led by the Hungarian partner.

Territorial coverage included the three Hungarian and the four Croatian counties along the border, and further four non-directly bordering counties from Croatia. From both sides of the border target area is characterised by low population density and lack of large urban areas. Although on both sides we can find a city above 100 thousand inhabitants (Osijek, Pécs), backbone of the settlement structure is dominated by small cities and larger towns. Similarity is the abundance of protected, nature conserved areas that are lagging behind. The two programme priorities included sustainable environment and tourism; and co-operative economy and human resources development. This programme funded only non-profit making organisations, and the two priorities differed significantly in terms of project size. Priority 1 for environment and tourism allowed projects between 50 thousand and 3 million euros, under the different measures, including investment elements; while priority 2 funded in a range of 50 and 500 thousand euros, with very limited or no investment activities in case of the single measures. 
Although the two programmes were very similar in their size - both financially and in their thematic focus - implementation-wise they were very different. While the Slovenia-Austria programme applied to all priorities and beneficiaries the same conditions, the Hungary-Croatia programme was more a composition of differently tailored measures, with different target groups and different financial conditions.

\section{Hypotheses and methodology}

The paper comes out from the hypotheses that governance structure of the given countries is reflected in the implementation of the programme and the allocation of funding. As the projects had to follow a joint objective, but had to be implemented in cooperation - with involvement of at least one partner from each side - cross-border cooperation provides an excellent test for comparison of governance practice.

The conducted analysis is based on primary project data taken from the final reports of the financed projects made available by the programme management bodies of the two programmes (Joint Technical Secretariats in Slovenia and Hungary). For cooperation activity the number of "projects parts" was taken into consideration. Project part (PP) is understood as part of a project implemented by a certain beneficiary within the partnership. A project is made of as many project parts as many partners are in the partnership. To proxy absorption of funding the amount of realised funding (reported, verified and reimbursed co-financing) has been used. Although these two figures are significantly correlating, their relationship is very important: if activity is higher than absorption, projects dominantly lack heavy investments (soft projects). While if absorption is higher than activity, hard projects, including investment elements, prevail.

In order to tackle geographical patterns of governance, for location of a project part the seat of the beneficiary organisation was considered. Generally, beneficiaries were eligible from the programmes areas only, however both programmes allowed exceptions under certain circumstances. The Slovenia-Austria programme allowed participation of partners from regions outside the target areas, with proper justification. The capital city of Vienna (Wien) - due to state level bodies - participated in two projects, while Nordburgenland - the location of Eisenstadt, the capital of Burgenland - with eight partners. Eisenstadt - due to its important role and proximity to the programme's target area - has been remained in the analysis. On the other hand, the federal capital city of Vienna proved to be an outlier from both aspects (high population, low activity in projects and absorption), therefore it has been eliminated from the analysis. In case of the Hungary-Croatia programme participation from regions outside the programme area was possible if the beneficiary maintained branch office in the programme area. If such office was available its location has been taken into consideration. In case of several such offices the one, which was geographically and thematically more connected to the project was considered. In case of no such branch office, the location where the project actually took place was taken into consideration. In the two latter cases the projects had to undergo additional data collection.

Finally, for the Slovenia-Austria programme 482 project parts (after exclusions), for the Hungary-Croatia programme 526 project parts have been included in the analysis, making up a database of 1008 records. 


\section{Analysis of activity patterns on different levels of the settlement network}

In order to carry out the analysis on local level, data on project partner level has been aggregated on LAU 2 level (municipalities, towns or cities). This approach enables the consideration of large urban centres together with their local direct neighbourhoods. On the other hand through this approach, efforts of the local administrations of small multi-settlement municipalities might be tackled (first of all Slovenia, but Austria and Croatia as well).

In order to define an applicable set of settlement categories suitable to the four countries, the following principles were taken into consideration:

- functions in the settlement network and population were treated equally;

- avoiding categories being empty in some countries;

- number of local units in the different categories should be proportional.

Finally six categories have been made: category 5 units include the existing (or potential) NUTS 2 centres that are in all cases cities with a population above 90000 . Municipalities below 2000 have become category 0 , that are having a very different significance in the analysed countries, due to their settlement structure particularities. The applied categories are seen in Table 2 and the three highest categories are mapped on Figure 1.

Table 2. Composition of categories of settlement in the analysis

\begin{tabular}{|c|c|c|c|c|c|c|}
\hline Category & Criteria & Austria & Slovenia & Croatia & Hungary & Total \\
\hline 5 & $\begin{array}{l}\text { Strong NUTS } 2 \text { regional centres, } \\
\text { cities with population above } \\
90000\end{array}$ & $\begin{array}{l}\text { Graz } \\
\text { Klagenfurt }\end{array}$ & $\begin{array}{l}\text { Ljubljana } \\
\text { Maribor }\end{array}$ & Osijek & Pécs & 6 \\
\hline 4 & $\begin{array}{l}\text { Functional co-centres of NUTS } 2 \\
\text { regions, strong NUTS } 3 \text { regional } \\
\text { centres, cities with population } \\
\text { above } 40000\end{array}$ & Villach & $\begin{array}{l}\text { Celje } \\
\text { Kranj }\end{array}$ & $\begin{array}{l}\text { Bjelovar } \\
\text { Varaždin }\end{array}$ & $\begin{array}{c}\text { Kaposvár } \\
\text { Nagykanizsa } \\
\text { Zalaegerszeg }\end{array}$ & 8 \\
\hline \multirow{2}{*}{3} & NUTS 3 centres below 40000 & $\begin{array}{c}\text { Deutschlandsberg } \\
\text { Eisenstadt } \\
\text { Leoben } \\
\text { Oberwart } \\
\text { Spittal an der Drau } \\
\text { Weiz } \\
\text { Wolfsberg }\end{array}$ & $\begin{array}{l}\text { Murska } \\
\text { Sobota } \\
\text { Slovenj } \\
\text { Gradec }\end{array}$ & $\begin{array}{l}\text { Čakovec } \\
\text { Koprivnica } \\
\text { Virovitica } \\
\text { Vukovar }\end{array}$ & - & \multirow{2}{*}{25} \\
\hline & $\begin{array}{l}\text { Further towns above } 20000 \\
\text { inhabitants }\end{array}$ & Kapfenberg & \begin{tabular}{|l} 
Jesenice \\
Kamnik \\
Ptuj \\
Škofja Loka \\
Slovenska \\
Bistrica \\
Velenje \\
\end{tabular} & $\begin{array}{l}\text { Križevci } \\
\text { Vinkovci }\end{array}$ & $\begin{array}{l}\text { Keszthely } \\
\text { Siófok } \\
\text { Komló }\end{array}$ & \\
\hline 2 & $\begin{array}{l}\text { Further towns, municipalities } \\
\text { with rights of a town (AT) }\end{array}$ & 14 & 13 & 11 & 16 & 54 \\
\hline 1 & $\begin{array}{l}\text { Municipalities with a population } \\
\text { more than } 2000\end{array}$ & 13 & 22 & 22 & 1 & 58 \\
\hline 0 & $\begin{array}{l}\text { Municipalities with a population } \\
\text { less than } 2000\end{array}$ & 15 & 3 & 4 & 22 & 44 \\
\hline Total & $x$ & 53 & 50 & 46 & 46 & 195 \\
\hline
\end{tabular}

Source: own edition. 


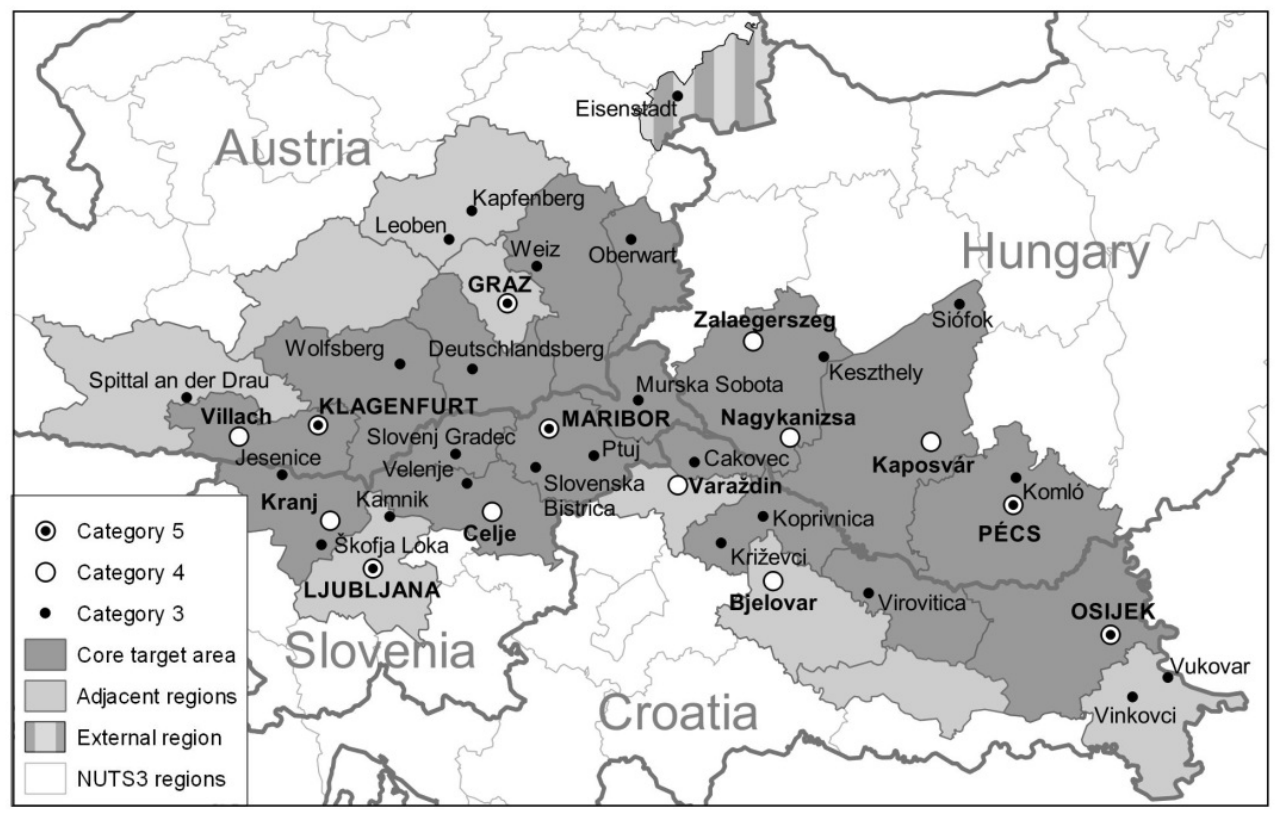

Figure 1. Location of the category 1, 2 and 3 LAU 2 units in the analysed programme areas Source: own edition.

Interesting to point out that although Obersteiermark West (Austria) and Požega-Slavonia (Croatia) have a potential category 3 town (Murau and Požega, respectively), these regional centres failed to get involved in any project. In these regions cross-border cooperation was carried by lower level local units.

Sorting out the most active LAU 2 units in case of the analysed countries, category 5 cities are per se among the most active ones, in Slovenia and Croatia category 3 and 4 cities are close behind, while in Austria and Hungary we see a somewhat more mixed pattern (Table 3).

In order to compare performance patters of the pair countries (Slovenia - Austria, Hungary Croatia) cumulative graphs, similar to the concentration curve, have been used that well visualises the contribution of the single categories to cooperation activity and absorption of funding.

In case of Austria and Slovenia (Fig. 2) a significant difference can be seen in the role of the different centres. In Austria the regional centres dominate both activity and funding: more than $50 \%$ is generated on this level. Lower category centres play a proportional role, even the smallest municipalities have a share of $10 \%$ from activities and a slightly less from funding. In case of Slovenia generally we can see a proportional concentration (parabolic) towards the higher categories, having a particularly strong category 3 concentrating about $25 \%$ in each variable. On the other hand category 5 concentrates only about $36.5 \%$. This strong role of the small urban centres might be due to the polycentric approach promoted by the Slovenian spatial policy. As for project size, activity and absorption run along each other, there are no particular differences in project sizes. Some below-average investment-orientation may be noticed in case of the small settlements in Slovenia, but in general no different approach may be detected in the different categories. 
Table 3. The most active LAU 2 units in the analysed countries, by number of PPs and realised funding

\begin{tabular}{|c|c|c|c|c|}
\hline Number & LAU 2 & Category & Number of PPs & Realised funding (euro) \\
\hline \multicolumn{5}{|c|}{ Austria } \\
\hline 1 & Klagenfurt & 5 & 55 & 7141829.26 \\
\hline 2 & Graz & 5 & 51 & 9426167.37 \\
\hline 3 & Eisenstadt & 3 & 8 & 1013209.13 \\
\hline 4 & Villach & 4 & 7 & 397427.39 \\
\hline 5 & Großweifersdorf & 0 & 5 & 1085146.61 \\
\hline 6 & Spittal an der Drau & 3 & 5 & 689813.76 \\
\hline \multicolumn{5}{|c|}{ Slovenia } \\
\hline 1 & Maribor & 5 & 54 & 6234918.56 \\
\hline 2 & Ljubljana & 5 & 46 & 4171901.35 \\
\hline 3 & Murska Sobota & 3 & 26 & 2775859.28 \\
\hline 4 & Kranj & 4 & 17 & 1860583.02 \\
\hline 5 & Ptuj & 3 & 15 & 2123670.72 \\
\hline 6 & Slovenj Gradec & 3 & 13 & 1085170.92 \\
\hline \multicolumn{5}{|c|}{ Croatia } \\
\hline 1 & Osijek & 5 & 86 & 9550153.50 \\
\hline 2 & Čakovec & 3 & 39 & 3777773.72 \\
\hline 3 & Koprivnica & 3 & 34 & 1277701.84 \\
\hline 4 & Virovitica & 3 & 22 & 1653268.49 \\
\hline 5 & Križevci & 3 & 15 & 1708971.93 \\
\hline 6 & Varaždin & 4 & 11 & 166293.04 \\
\hline \multicolumn{5}{|c|}{ Hungary } \\
\hline 1 & Pécs & 5 & 86 & 10757085.02 \\
\hline 2 & Zalaegerszeg & 4 & 26 & 1108233.78 \\
\hline 3 & Kaposvár & 4 & 25 & 1369108.35 \\
\hline 4 & Nagykanizsa & 4 & 18 & 1668136.40 \\
\hline 5 & Szigetvár & 2 & 10 & 491535.88 \\
\hline 6 & Tótszerdahely & 0 & 7 & 1210698.04 \\
\hline
\end{tabular}

Source: own edition upon programme data.

Comparing Hungary and Croatia differences are, again, very visible (Fig. 3). In Hungary the relatively strong contribution (around 15\%) of the small municipalities (category 0 ) is noticeable, also the outstanding performance of the small towns (category 2), which represent a nearly $17 \%$ share from activity, and a nearly $23 \%$ share from absorption. These lower categories in Croatia play a proportional role. Even a more definite participation is represented by the small NUTS 3 centres in Croatia, responsible for about $40 \%$ of the activities and $36.7 \%$ of the funding. This result may be caused by the strong role of the county seats, even the smaller ones, in territorial governance that are the engines of cross-border cooperation. NUTS 3 centres in Hungary, on the other hand, play a much weaker role. Similar performance is detected on level of the two large cities, however Pécs seems to have a somewhat stronger concentration role than Osijek. In terms of project size, for Hungary smallest municipalities and category 2 and 3 towns preferred heavier projects, while larger cities (county centres under category 4 and 5 ) were dominated by soft projects. For Croatia these patterns are similar, however project size was in general lower than in Hungary, especially category 3 and 4 centres preferred relatively soft activities. 


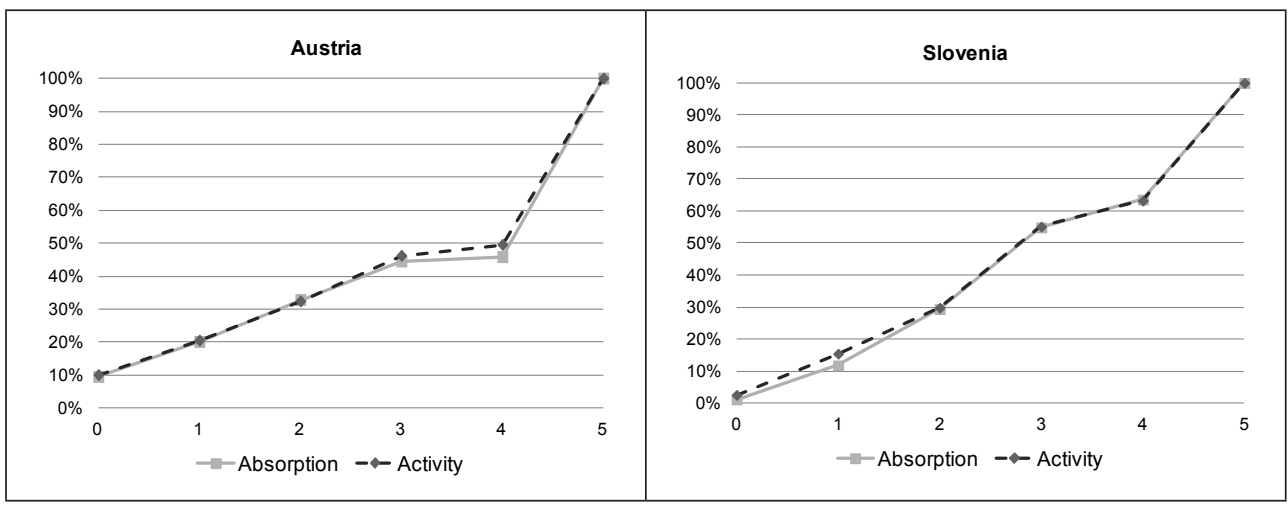

Figure 2. Concentration curve of Austria and Slovenia Source: own edition upon programme data provided by JTS.

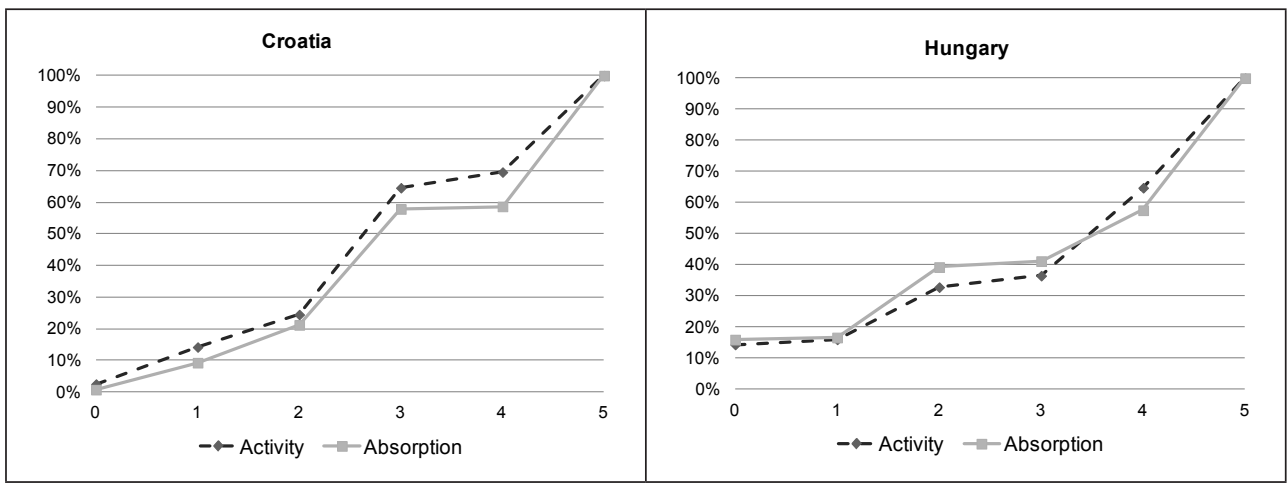

Figure 3. Concentration curves of Croatia and Hungary

Source: own edition upon programme data provided by JTS.

Comparison of the two indicators for all four countries (Fig. 4), in terms of activity on the lowest level (category 0) Hungarian municipalities are the most active, but categories 0-2 play more or less an equal role in each country. Judged upon the middle categories Croatia is the most decentralised, followed by Slovenia that are characterised by their strong network of small towns, which are the engines of cross-border cooperation. In general Hungary and Austria seem to be the most centralised, however Austria clearly stands out. The same comparison for absorption shows similar patterns, however the strong investment-orientation in Hungary under category 0 and 2 are particular. Similarities of Croatia and Slovenia are more apparent: low absorption on lower level and a strong concentration in the smaller regional centres. On the other hand category 5 centres exercised more concentration in all countries in financial terms, except for Ljubljana and Maribor in Slovenia. 


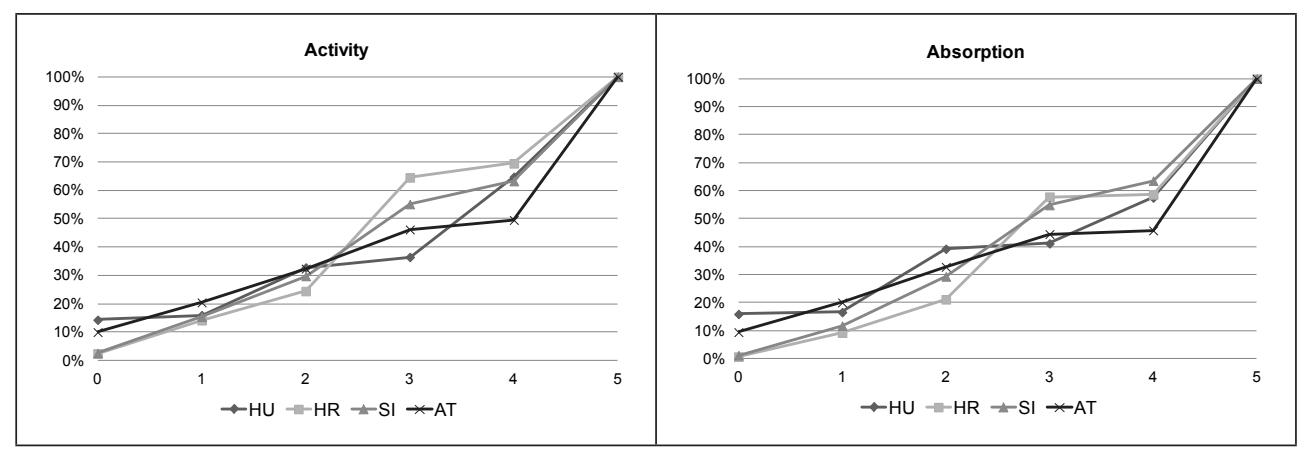

Figure 4. Comparing concentration curves of activity and absorption Source: own edition upon programme data provided by JTS.

\section{Comparison of organisational types of cooperating beneficiaries}

In order to tackle territorial governance practice more in detail it is worth to investigate the organisational forms of beneficiaries participating in cooperation projects. Both programmes' monitoring system classified the funded beneficiaries in slightly different ways that had to be harmonised, in order to apply categories referring to legal status (public, private, civil) and the different levels of governance (local, regional, national). As each beneficiary had to be classified into one category, the following categories were defined:

- NGO: non-profit civil organisations (association, foundation) established by non-public actors;

- non-profit company: bodies established by public authorities operating as non-profit companies or public institutions that may be local, regional or national;

- public administration on local, regional or national level;

- private companies: involving both for-profit companies (in case of the Slovenia-Austria programme) and private non-profit companies (Hungary-Croatia programme);

- research institutes established by public bodies, dealing with research, development and innovation;

- universities or other public high education institutions;

- other education and training institutions, including public primary and secondary education institutions.

In case of the Slovenia-Austria programme the analysis shows the outstanding role of enterprises and NGOs: these two types are responsible for more than half of the total activity. In Austria regional public administration is another key player, on the other hand - both as public administration bodies or their non-profit organisations - the local level plays a minor role. In Slovenia partnership is dominated by regional non-profit organisations, local governments and the academic society (Fig. 5). In terms of project size, in Austria private companies tend to be more investment-oriented, similar approach is detected in case of regional governmental bodies. On the Slovenian side similar clear investment-orientation is not visible, however regional non-profit companies are standing out. 


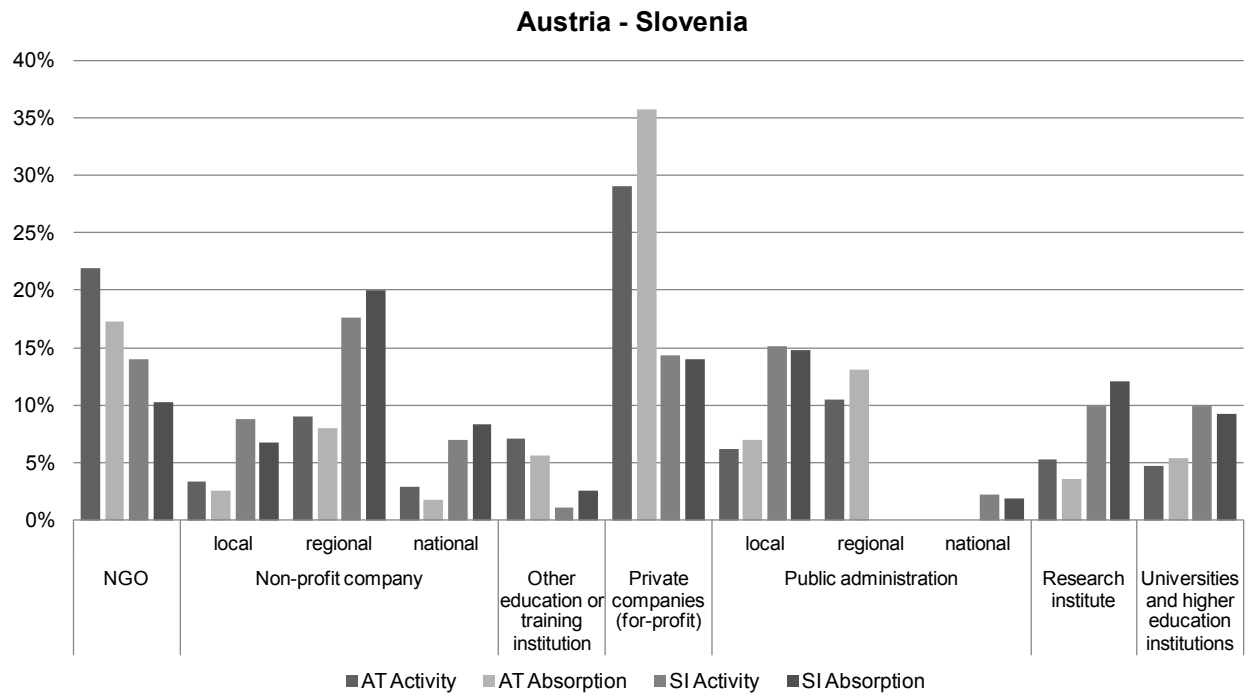

Figure 5. Distribution of activity and absorption by organisation types in case of the Slovenia-Austria programme

Source: own edition upon programme data provided by JTS.

In case of the Hungary-Croatia programme generally the local (local governments) and the national public authorities have the highest absorption: their share in funding overdoes their share in activity. However, while in Hungary local governments are funded significantly above their activity ratio ( $32 \%$ vs. $20.5 \%$ ), in Croatia this gap is minimal. Conclusion is that in Hungary local governments tend to use cross-border cooperation funding for realisation of their local investment projects, while in Croatia hard and soft activities are more balanced. National bodies play a more symmetric role (Fig. 6).

Regional bodies show a very different activity pattern. The Croatian side is more active on regional level, both as public administration or their non-profit bodies. On the Hungarian side lower activity is accompanied with smaller project size. In Croatia they are not only more active, but their projects are more investment-oriented. Therefore, activity of the national non-profit companies in Hungary is higher, as usually infrastructural projects are addressed to national non-profit bodies. Similar Hungarian particularity is the activity of private non-profit companies and a higher involvement of NGOs. 


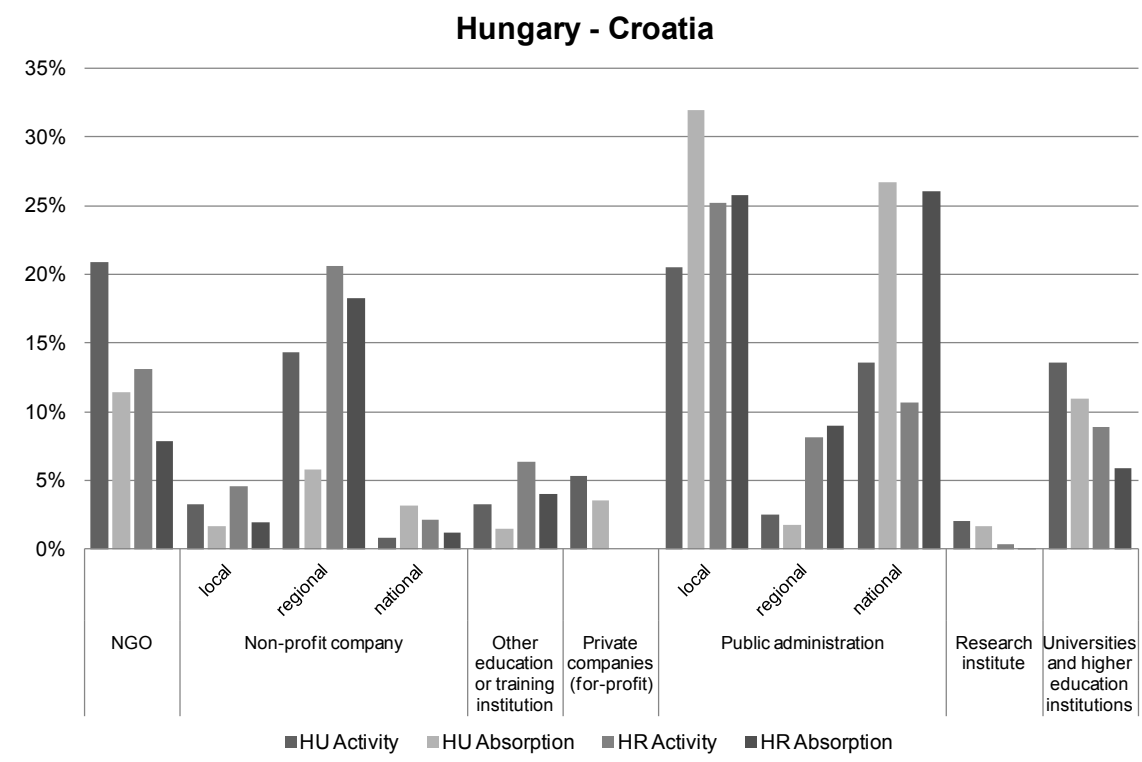

Figure 6. Distribution of activity and absorption by organisation types in case of the Hungary-Croatia programme

Source: own edition upon programme data provided by JTS.

\section{Conclusions}

Cooperation between Slovenia and Austria has a strong historical background: ties of Slovenia to the neighbouring regions of Austria and the West have been an important linkage in the history of regional cooperation in Central Europe. The status of republic within SFRY brought Slovenia the opportunity to open, however independent Slovenia retained centralised administrative structures: sub-national units are only statistical with limited development capacity, therefore local units and their development bodies must be the key players in cross-border cooperation. In case of Hungary and Croatia - in spite of similar historical background - cross-border cooperation was hindered during the cold war, later war events put it to minimum. Recovery of cooperation has been speeded up by accession to the EU in 2013, but strong historical and physical division still exists. Due to recent public administration reforms territorial governance structures have become similar: the counties have become the key players, however Croatia systematically developed its counties institutions, while in Hungary putting counties into focus of regional development was a result of failed regionalisation.

These differences and similarities are very well reflected when analysing cross-border cooperation in terms of activity in cooperation projects and absorption of funding on different levels of the settlement structure. Strong regional centres in Austria dominate cross-border cooperation the most out of the four countries. Similar relative concentration is visible in case of Hungary, however the relative strength of Pécs - home of several state agencies and a large university - is coming from the weaknesses of the other county structures. On the other hand Slovenia and Croatia 
are mode decentralised on NUTS 3 level, again, with different background. In Slovenia the locally founded development bodies operate in the smaller towns, while in Croatia even the smaller county seats host active development bodies that are standing out is absorption as well.

Analysis of the institutional structure of beneficiaries shows the same conclusion, from a different angle. While in Austria carriers of cross-border cooperation are the private companies, in Slovenia and Croatia regional bodies seem to have the driving force. In Croatia role of the state is stronger, especially in heavy projects, while Hungary brings the example of a stark state involvement, due to recent reforms in public administration. Similarity of the three post-socialist countries is the strong involvement of the local level, providing a tool of financing local development actions through cross-border cooperation.

\section{Acknowledgements}

Research for this publication has been supported by National Research, Development and Innovation Office - NKFIH: grant \#NN 114468 (Change and Continuity in Hungarian Spatial Imaginaries: Nationality, Territoriality, Development and the Politics of Borders).

\section{References}

AEBR, 1997. The EU Initiative INTERREG and future developments. Association of European Border Regions, https://www.aebr.eu/files/publications/interreg_97.en.pdf [16 July 2018].

Bali L., 2012. A magyar-horvát határon átnyúló kapcsolatok jelene és jövője [Present and future of Hungarian-Croatian cross-border cooperation]. Underground Kiadó.

Bojar, E., 2008. Euroregions in Poland. Tijdschrift voor economische en sociale geografie, vol. 5, pp. 442-447.

Bundeskanzleramt, ÖSB Consulting, 2004. Systemische Evaluierung des Regionalmanagements in Österreich, Kurzfassung [Systematic evaluation of Regional managements in Austria, Summary]. http:// archiv.bka.gv.at/DocView.axd?Cobld=9550 [30 July 2018].

CADSES, 2006. INTERREG IIIB CADSES Project Book-Advancing Transnational Cooperation. http://www. interreg-central.de/fileadmin/ccp/Programm/CADSES_Projectbook.pdf [10 March 2016].

CBC, 2007. Operational Programme Cross-border Cooperation Slovenia-Austria 2007-2013. CCI Number: 2007 CB163PO054.

CBC, 2013. Hungary-Croatia Cross-border Co-operation Programme. Programming document for the programming period 2007-2013. CCI Number: 2013CB163PO002, http://www.hu-hr-ipa. com/en/file_download/197 [7 September 2017].

CESCl, 2016. Crossing the Borders - Studies on cross-border cooperation within the Danube Region. Case Study the Euroregion Danube-Drava-Sava. Central European Service for Cross-border Initiatives, European Institute for Cross-border Studies. http://institute.cesci-net.eu/tiny_mce/uploaded/ EUSDR_Part_Two_13_DanubeDravaSava.pdf [24 October 2016].

Csapó J., Čelan T. J., Trócsányi A., 2015. A határmenti együttmüködés hatásai a területi fejlődésre a magyar-horvát szakasz példáján az EU tervezési mechanizmusának tükrében (2007-2013) [Impacts of cooperation in border areas on territorial development on example of the Hungary-Croatia border area, in light of the EU planning mechanism (2007-2013)]. Területfejlesztés és Innováció, vol. 9, no. 2, pp. 22-31.

Delo, 2008. Slovenija išče konsenz o pokrajinah že več kot desetletje [Slovenia has been seeking consensus on the regions for more than a decade]. http://www.delo.si/novice/slovenija/slovenija-isce-konsenz-o-pokrajinah-ze-vec-kot-desetletje.html [20 July 2016]. 
Dubarle P., Mezei C., Pámer Z., 2011. Regional development programmes. [in:] G. Horváth, Z. Hajdú (eds.) Regional Transformation Processes in the Western Balkan Countries. Hungarian Academy of Sciences Centre for Regional Studies, Pécs, pp. 570-601.

Đulabić V., Manojlović R., 2011. Administrative Aspects of Regional and Cohesion Policy in Croatia. [in:] Search of a Better Coordination of Parallel Processes. Croatian and Comparative Public Administration, vol 11, no. 4, pp. 1041-1074.

EC, 2006. Council Regulation (EC) No 1083/2006 of 11 July 2006 laying down general provisions on the European Regional Development Fund, the European Social Fund and the Cohesion Fund and repealing Regulation (EC) No 1260/1999.

Hajdú Z., 1996. Emerging conflict or deepening cooperation? The case of the Hungarian border regions. [in:] J. W. Scott et al. (eds.) Border Regions in Functional Transition: European and North American Perspectives on Transboundary Interaction. Institut für Regionalentwicklung und Strukturplanung, Berlin, pp. 193-211.

Harguindéguy J.-B., Bray Z., 2009. Does cross-border cooperation empower European regions? The case of INTERREG III-A France - Spain. Environment and Planning C: Government and Policy, vol. 27, pp. 747-760.

INTERACT, 2015. Fact Sheet; Historical view of Interreg / European Territorial Cooperation. www.interact-eu.net/download/file/fid/2902 [16 July 2018].

Ivanišević S., Kopric' I., Omejec J., Simovic J., 2001. Local Government in Croatia. [in:] E. Kandeva (ed.) Stabilization of Local Governments. Local Government and Public Service Reform Initiative. Open Society Institute. Budapest.

Lados M., 2005. Programértékelés a 2000. évi Magyarország-Ausztria Phare CBC Kisprojekt Alap példáján [Programme evaluation on example of the year 2000 Hungary-Austria Phare CBC Small Project Fund]. Tér és Társadalom, vol. 2, pp. 101-126.

Land Steiermark, 2016. Neue Förderperiode EUREGIO Steiermark/Slowenien 2007-2013. http://www. raumplanung.steiermark.at/cms/beitrag/10820941/265384/ [10 March 2016].

Lindstrom N., 2005: Europeanization and sub-national governance in Slovenia. ECPR Joint Sessions of Workshops, Granada, 15-19 April 2005, https://ecpr.eu/Filestore/PaperProposal/76d206bf-565948c4-9d57-0c6887afa72c.pdf [8 June 2016].

Manzella G. P., Mendez C., 2009. The turning points of EU Cohesion policy. http://ec.europa.eu/regional_ policy/archive/policy/future/pdf/8_manzella_final-formatted.pdf [2 July 2018].

Nadalutti E., 2015. The Effects of Europeanization on the Integration Process in the Upper Adriatic Region. Springer.

ÖREK, 2010. Ausgangslage und Trends, Herausforderungen und Anforderungen, Lösungsvorschläge und Empfehlungen zur österreichischen Raumpolitik. Ergebniszusammenfassung, Arbeitsgruppe V, Raumentwicklung. ÖREK, https://www.oerok.gv.at/fileadmin/Bilder/2.Reiter-Raum_u._Region/1. OEREK/OEREK_2011/AGs/5._AG_V_Raumentwicklung/B_Ergebniszusammenfassung_AG_V_Raumentwicklungspolitik.pdf [2 September 2017].

Pálné Kovács I., 2009. Europeanisation of Territorial Governance in Three Eastern/Central European Countries. Halduskultuur, 2009, vol. 10, pp. 40-57.

Pámer Z., 2007. The European integration and regional policy of the West Balkan countries. [in:] Z. Hajdú, I. Illés, Z. Raffay (eds.) Southeast-Europe: State Borders, Cross-Border Relations, Spatial Structures. Centre for Regional Studies of the Hungarian Academy of Sciences, Pécs, pp. 119-160.

Pámer Z., 2011. The possibilities of implementing the European Grouping of the Territorial Cooperation in South Transdanubia. [in:] A. Ágh, T. Kaiser, B. Koller (eds.) The New Horizons of the Cohesion Policy in the European Union: the Challenge of the Danube Strategy. Blue Ribbon Research Centre King Sigismund College, Budapest, pp. 176-194.

Perkmann M., 2003. Cross-border Regions in Europe. Significance and Drivers of Regional Cross-border Cooperation. European Urban and Regional Studies, vol. 10, no. 2, pp. 153-171.

Perkmann M., 2007. Policy entrepreneurship and multilevel governance: a comparative study of European cross-border regions. Environment and Planning C: Government and Policy, vol. 25, pp. 861-879.

Popescu G., 2008. The conflicting logics of cross-border reterritorialization: Geopolitics of Euroregions in Eastern Europe. Political Geography, vol. 27, pp. 418-438. 
Rácz Sz., 2016. Horvátország térszerkezete [The spatial structure of Croatia]. Tér és Társadalom, vol. 30, no. 3, pp. 81-104.

Rácz Sz., 2017. Main characteristics of Hungarian-Croatian political relations and Cross-border Co-operations. Geographica Pannonica, vol. 21, no. 1, pp. 54-67.

Rechnitzer J., 2012. A régiók az elmúlt 20 év területi politikájában [Regions in the past 20 years of territorial policy]. [in:] Z. Bajmócy, I. Lengyel, G. Málovics (eds.) Regionális innovációs képesség, versenyképesség és fenntarthatóság. JATEPress, Szeged, pp. 175-194.

RSRS, 2007. Revizijsko poročilo o INTERREG IIIA Slovenija-Avstrija. Proces izbora projektov v obdobju od 2004 do 2006 [Revision report about INTERREG IIIA Slovenia-Austria. Process of project selection in the period of 2004-2006]. Računsko sodišče Republike Slovenije, http://www.rs-rs.si/rsrs/rsrs. nsf/I/K8360171D0B911190C12573590054E715/\$file/Interreg-IIIA.pdf [4 April 2016].

Scott J. W., 2013. Territorial Cohesion, Cross-border Co-operation and the EU's Political Identity: A Brief Observation. [in:] I. Pálné Kovács, J. Scott, Z. Gál (eds.) Territorial Cohesion in Europe - For the 70th anniversary of the Transdanubian Research Institute. Institute for Regional Studies, Centre for Economic and Regional Studies, Hungarian Academy of Sciences, Pécs, pp. 73-84.

Scott J. W., Liikanen I., 2010. Civil Society and the 'Neighbourhood' - Europeanization through Cross-Border Cooperation? [in:] J. W. Scott, I. Liikanen (eds.) European Neighbourhood through Civil Society Networks? Routledge.

Svensson S., Ocskay G., 2016. Overview of the EGTCS around Hungary. Central European Service for Cross-border Initiatives. http://cesci-net.eu/tiny_mce/uploaded/EGTC_Overview_CESCl_.pdf [24 October 2016].

Törvény, 2011. 2011. évi CLXXXIX. törvény Magyarország helyi önkormányzatairól [Act 2011: CLXXXIX on local governments of Hungary]. Text applicable on 18 January 2018.

van Houtum H., 2000. An Overview of European Geographical Research on Borders and Border Regions. Journal of Borderland Studies, vol. XV, no. 1, pp. 57-83.

VÁTI, 2004. Az INTERREG Magyarországon - Kézikönyv [The INTERREG in Hungary - Handbook]. Technical Assistance for the INTERREG Programme and Project Development EuropeAid/116361/D/SV/HU.

Zimmermann F. M., Kubik K., 2003. Grenzüberschreitende Kooperationen: Der Raum Graz - Maribor [Cross-border cooperation: the Graz - Maribor area]. Ländlicher Raum, vol. 3, https://www.bmlfuw. gv.at/dam/jcr:f5e2c70d-7507-44dd-bba5-6254351bd795/Zimmermann_end2\%5B1\%5D.pdf [10 March 2016].

Zakon, 2007. Zakon o lokalni samoupravi [Local government act]. Uradni list RS 94/2007, Pročiščeno besedilo.

Zakon, 2009. Zakon o razvojni podpori Pomurski regiji v obdobju 2010-2017 [Pomurje region development subsidy act in the 2010-2017 period]. (ZRPPR1015), Uradni list RS 87/2009, 82/2015.

Zakon, 2011. Zakon o spodbujanju skladnega regionalnega razvoja [Act on promoting harmonious regional development]. (ZSRR-2), neuradno prečiščeno besedilo št. 2. Uradni list RS 20/2011, $57 / 2012,46 / 2016$.

Zakon, 2014. Zakon o regionalnom razvoju [Regional development act]. Narodne novine 174/2014. 